\title{
架構付無開口壁の剪断抵抗に関する研究 (第2 報)
}

I. 研究目的

II. 実驗方法

$\S 2.1$ 試験体の形状、配筋及び符号

$\S 2.2$ 試験体の性状

$\$ 2.3$ 荷重方法

$\S 2.4$ 测定方法

\section{III. 実験結果とその検討}

$\$ 3.1$ 剪断剛性について

$\$ 3.2$ 亀裂荷重について

$\S 3.3$ 最大耐力施つい

$\$ 3.4$ 終局敷力について

$\$ 3.5$ 補強問題について

謝辞

参考交献

附圆

$\$ 3.3$ 最大耐力について

\section{i. 单独架構 F}

終局強度理論によつて検討した結果は第 3.7 表に示す ように実験結果と極めて良く一致した。

第 3.7 表 単独架構の最大耐力 $Q_{\max }$

\begin{tabular}{|c|c|c|c|}
\hline & \multirow{2}{*}{ 実験結果 } & \multicolumn{2}{|c|}{ 終局強度理論の算定結果 } \\
\hline & & 大崎式 ${ }^{11)}$ & 旗村式 ${ }^{12)}$ \\
\hline$Q_{\max }($ ton $)$ & 7.4 & 7.5 & 7.4 \\
\hline$Q_{\text {max }}$ 支配原因 & 梁端の曲げ & 梁端の曲げ & 梁端の曲げ \\
\hline
\end{tabular}

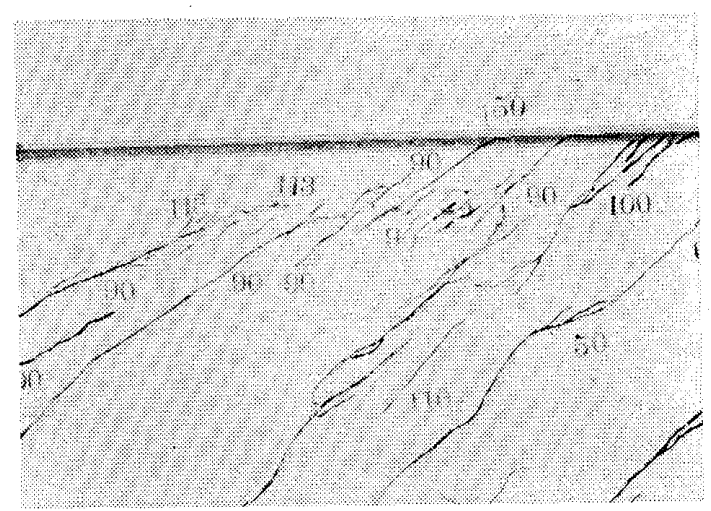

第 3.11 図 架構付鉄筋コンクリート壁に於ける 壁の水平入リップ状剘断破壞の状況（溒験体 8 CWF-BB の正側加力話験結果)

註 龜裂の脇飞捺印してある数值は該弫裂部発生時の対角線方向荷重 $P($ ton $)$ を示す。

$\begin{array}{lllll}\text { 正会員 } & \text { 富 } & \text { 井 } & \text { 政 英* } \\ \text { 正会 } & \text { 大 } & \text { 崎 } & \text { 順 䓞** }\end{array}$

備考 終局強度理論の算定結果はいずれも 梁端の曲げモーメント $M=0.423 Q($ ton $\cdot \mathrm{m})$ 梁の軸方向力 $N=0.500 Q$ (ton) を考慮して求めたものである。

ii. 架構付鉄筋コンクリート壁 CWF

壁の斜張亀裂の発生によつてコンクリートが負担でき なくなつた斜張力を充分取りきれるだけの強さがある周 辺架構を有する場合には壁のスリップ状剪断強度 $c^{F} F_{s s}$ によつて最大耐力 $Q_{\max }$ が支配される（第 3.11 図及び 第 3.12 図参照)。(3.14) 式より $\kappa^{\prime}{ }_{w} Q / A_{w}$ が壁の平 均剪断応力度 $\ddot{\tau} \cdot$ を学るものと考劣ると、最大耐力 $Q_{\max }$ は次式で与光られる。

$$
\begin{aligned}
& Q_{\max }=\frac{A_{w}}{\kappa^{\prime}{ }_{w}}{ }_{c} F_{s s} \\
& { }_{c} F_{s s}: \text { コクリபトのスリップ状剪断強度 }
\end{aligned}
$$

壁がスリップ状剪断破壊を起した $6 \mathrm{CWF}, 8 \mathrm{CWF}$ の各 試験体 (第 3.1 表参照) 及び 武藤研究室の実験 ${ }^{13}$ から スリップ状剪断強度 ${ }_{c} F_{s s}$ を求めてみると第 3.8 表のよ 万になり、コンクリートの圧縮強度 ${ }_{c} F_{c}$ の約 0.22 倍 そなつている。以上正側加力試験の結果から求めたも のだが、負側加力試験の場合は正㑡加力試験の耐力の $85 \%$ 位の耐力乙か期待出来ない（第 3.1 表）から、繰: 返し荷重を対象とした場合のスリップ状剪断強度 ${ }_{c} F_{s s}$ 注コンクリートの压縮強度 ${ }_{c} F_{c}$ の 0.2 倍と見て括いた 方が安全である。

単調荷重の場合 : ${ }_{c} F_{s s}=0.22{ }_{c} F_{c}$

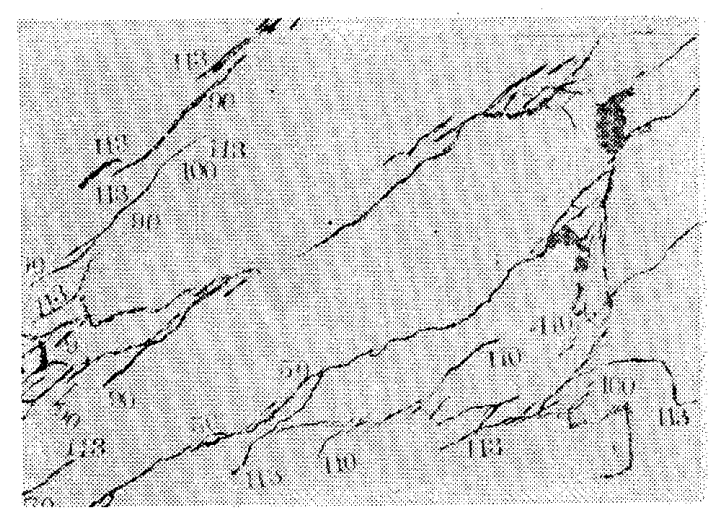

第 3.12 図 架構付鉄筋コンクリート壁飞於ける 壁の水平及び鉛直スリップ状剪断破壞の状況（語 験体 $8 \mathrm{CWF}-\mathrm{BB}$ の正側加力試験結果)

* 九州大学助教授

** 建設省建築研究所研究員 (本稿受理 昭和 30 年 11 月) 
繰返荷重の場合 : ${ }_{c} F_{s s}=0.20{ }_{c} F_{c}$

(3.31) 式及び (3.32) 式の関係をそれぞれ(3.30) 式

単調荷重の場合 $: Q_{\max }=\frac{A_{w}}{\kappa^{\prime}{ }_{w}} 0.22{ }_{c} F_{c} \ldots$

に代入すれば、最大耐力 $Q_{\max }$ は次式で与えられる。

繰返荷重の場合 $: Q_{\max }=\frac{A_{w}}{\kappa^{\prime}{ }_{w}} 0.20{ }_{c} F_{c}$

第3.8 表 架構付鉄筋コンクリート壁のスリップ状咅断強度 ${ }_{c} F_{s s}$ と压縮強度 ${ }_{c} F_{c}$ の関係

\begin{tabular}{|c|c|c|c|c|c|c|c|c|c|c|}
\hline 溒験体符号 & $\xi$ & $\eta$ & $\begin{array}{c}A_{w} \\
\left(\mathrm{~cm}^{2}\right)\end{array}$ & $\kappa^{\prime}{ }_{w}$ & $\begin{array}{l}Q_{\max } \\
(\text { ton })\end{array}$ & $\left(\begin{array}{c}c^{F}{ }_{s s} \\
\left(\mathrm{~kg} / \mathrm{cm}^{2}\right)\end{array}\right.$ & $\left(\mathrm{kg} / \mathrm{cm}^{F^{2}}\right)$ & $\begin{array}{l}{ }_{c} F_{s s} \\
{ }_{c} F_{c}\end{array}$ & $\begin{array}{l}\text { 柱の断面積 } \\
\text { 柱の必要断面積 }\end{array}$ & $\frac{\text { 梁の断面積 }}{\text { 梁の必要断面積 }}$ \\
\hline $6 \mathrm{CWF}$-平均 & 800 & 0.200 & 1620 & 0.95 & 58.2 & 34.1 & 154 & 0.22 & $\frac{900 \mathrm{~cm}^{2}}{720 \mathrm{~cm}^{2}}=1.25$ & $\frac{600 \mathrm{~cm}^{2}}{480 \mathrm{~cm}^{2}}=1.25$ \\
\hline $8 \mathrm{CWF}$-平均値 & 0.800 & 0.267 & 2180 & 0.96 & 89.7 & 39.0 & 187 & 0.21 & $\frac{\mathrm{m}^{2}}{\mathrm{~m}^{2}}=0.94$ & $\frac{600 \mathrm{~cm}^{2}}{640 \mathrm{~cm}^{2}}=0.94$ \\
\hline PC-平 & .715 & 0.333 & 72 & 0.90 & 3.8 & 47.5 & 195 & 0.24 & $\frac{36 \mathrm{~cm}^{2}}{30 \mathrm{~cm}^{2}}=1.20$ & $\frac{36 \mathrm{~cm}^{2}}{20 \mathrm{~cm}^{2}}=1.80$ \\
\hline $\mathrm{RC}$-平均值 & 0.715 & 0.333 & 72 & 0.90 & 4.7 & 58.7 & 255 & 0.23 & $\frac{36 \mathrm{~cm}^{2}}{30 \mathrm{~cm}^{2}}=1.20$ & $\frac{36 \mathrm{~cm}^{2}}{20 \mathrm{~cm}^{2}}=1.80$ \\
\hline
\end{tabular}

備考 下 2 欄代武藤研究室の实験結果 $\left.{ }^{13}\right)$ である。試験体符号 PC：無筋壁，RC：有筋壁

実験結果によれば、周辺架構の壁に対する相対的束縛 作用が大きい試験体 $6 \mathrm{CWF}$ 怯無筋壁及び有筋壁共初重 裂が壁面内で止り最大耐力 $Q_{\max }$ が壁のスリップ状剪断 破壊次よつて支配されている。相対的束縛作用が前者よ り小さい試験体 $8 \mathrm{CWF}$ になると有筋壁は黾裂発生時に コンクリートが負担できなくなつた斜張力の一部を壁筫 が負担するとともに衝擊緩和の作用もなすため初車裂が 壁面内で止り、最大耐力 $Q_{\max }$ が壁のスリップ状剪断 破壊に上つて支配されているが、無筋壁は初黾裂が梁に 達し最大耐力 $Q_{\max }$ は壁のスリップ状剪断破壊によつて 支配されてはいるが梁端の剪断破壊をる同時伴つてい る。相対的束縛作用が最す小さい試験体 $10 \mathrm{CWF}$ は有 穊壁注初重裂がやっと壁面で止つているが最大耐力 $Q_{\max }$ は梁端の尊断破壊によつて支配され無筋壁は初重

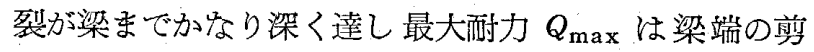
断破壊によつて支配されている。以上の事実から判断す ると、試験体 $8 \mathrm{CWF}$ は最大耐力 $Q_{\max }$ が壁のスリップ 状剪断破壊で支配される相対的束縛作用の限界沉るも のと考光られる。又との限界までの架構付壁に対してそ の初重裂を壁面内溜め、最大耐力 $Q_{\max }$ を確実に壁 のスリップ状剪断破壊によつて支配させるとともに周辺 架構の損傷を最小限度に止めて災害後の補修を容易なら 乙める見地加ら壁筋比関する最低規準を定めると、多 少の安全率をとつても

$$
\left.\begin{array}{l}
\text { 縱筋比: } p_{v} \geqq 0.2 \% \\
\text { 横筋比: } p_{h} \geqq 0.2 \%
\end{array}\right\}
$$

あれば充分と考克られる（註： $8 \mathrm{CWF-AA}$ $0.176 \%$ で初重裂が壁面内に留り、最大耐力 $Q_{\max }$ が壁 のスリップ状剪断破壊によつて支配されている)。

周辺架構の壁汶対する相対的束縛作用の限界を、初禹 裂発生時飞壁のコンクリートが負担できなくなつた斜張 力を周辺架構の各部材のコンクリート断面が全部負担で

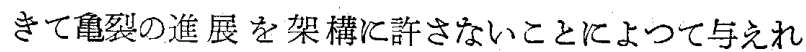

ば、各部材の必要断面は次のようになる。 柱の必要断面積 : $A_{C} \geqq \frac{1}{2} l^{\prime} t$

梁の必要断面積 : $A_{B} \geqq \frac{1}{2} h^{\prime} t$

但し $l^{\prime}:$ 架構の内のりスパン $h^{\prime}:$ 架構の内のり高さ $t:$ 壁の厚さ

(3.36) 式の結果からも本試験の範囲では試験体 $8 \mathrm{C}$ WF がその限界炕むることが知られる（第 3.8 表参 照)。

初重裂を壁面内に留めるには (3.35) 式で与兄られる 壁筋比及び (3.36) 式で与兄られる各部材の必要断面積 の他、各部材の最小径をる規定する必要がある。重裂の 進展抑制汶対して部材の巾及び丈が対等飞効くものとす れば、先述の試駼結果から次のような制限が必要と考元 られる。

$$
\left.\begin{array}{l}
\text { 柱の最小径 }: \sqrt{\frac{l^{\prime} t}{3}} \text { 以上、且つ } 2 t \text { 以上 } \\
\text { 梁の最小径 }: \sqrt{\frac{h^{\prime} t}{3} \text { 以上、且つ } 2 t \text { 以上 }}
\end{array}\right\}
$$

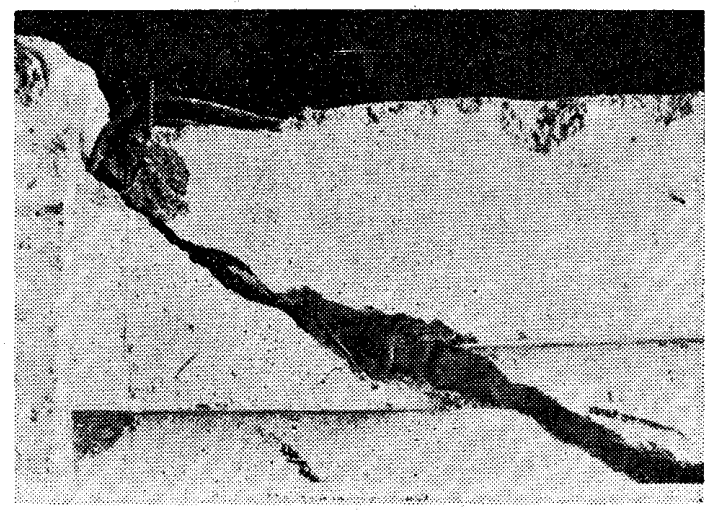

第 3.13 図 架構付鉄筋コンクリート壁に於け る梁の剪断破壞の状況（馀験体 $10 \mathrm{CW} \mathrm{F-AA}$ の負㑯加力詿験結果） 
以上は最大耐力 $Q_{\max }$ が壁のスリップ状剪断強度 ${ }_{c} F_{s s}$ そよつて支配される場合について述べたるのであるが， (3.36) 式及び (3.37) 式の規定に 合格し々い場合には 最大耐力 $Q_{\max }$ が周辺架構の部材端の剪断破壊によつて 支配されることも予想しなければならず（第 3.13 図及 び第 3.14 図参照)

$$
\frac{A_{w}{ }_{{ }^{\prime}} F_{s s}}{\kappa^{\prime}{ }_{w}}>Q_{\max }>Q_{c r}=\frac{A_{w}}{\kappa_{w}{ }_{c}} F_{s}
$$

となり、部材の剪断耐力がはつきり究明されていない現 状では解決が困難をなる。ゆ六に先述したように災害後 の補修と云う問題から見ても (3.36) 式及び (3.37) 式 を満足して最大耐力 $Q_{\max }$ が (3.30) 式で与兄られる 形状のものを設計するととが好をしい。

完全洞辺架構がない壁式構造の単独壁阅する関す最大 耐力 $Q_{\max }$ の算定法飞ついては別報をを参照されたい。

iii. 架構付補強ブロック壁 BWF

\$3.2で述べて招いたようと、壁の斜張重裂発生前か ら補強ブロック壁と周辺架構の接着面には重裂が迴つて 招り、最大耐力 $Q_{\max }$ 前復にははとんど別々な変形を起 し、周辺架構々単独架構飞近い変形を示している(附 3.10 図及び附 3.11 図参照) ととから、最大耐力 $Q_{\max }$ は次の累加強度式で求めるのが良いと考穴られる。

$$
Q_{\max }={ }_{F} Q_{\max }+{ }_{B} Q_{\max }
$$

${ }_{F} Q_{\text {max }}$ : 周辺架構を単独架構と見做した場合の最

$$
\begin{array}{r}
\text { 大耐力 } \\
{ }_{B} Q_{\max } \text { : 補強ブロ } \\
\text { ック壁の } \\
\text { 最大耐力 }
\end{array}
$$

補強ブロック壁の最 大耐力 ${ }_{B} Q_{\max }$ 江本 実験の試験体 BWF のよう飞周辺架構の 壁汶対する相対的束 縛作用が大きい場合 そは補強ブロックの スリップ状剪断強度 ${ }_{B} F_{s s}$ 亿支配され， 次式で与兄られる。 ${ }_{B} Q_{\max }=A_{w B}^{\prime} F_{s s}$ (3.40)

$A^{\prime}{ }_{w}$ : 架構内のり

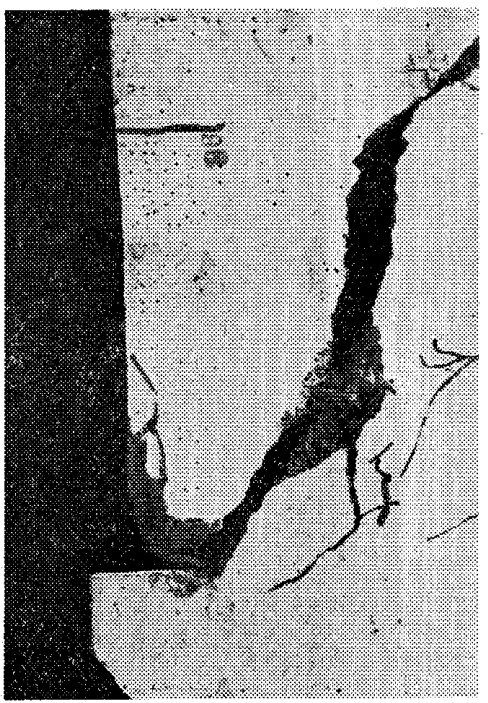

第 3.14 図架構付鉄筋コンクリ 一下壁汇於ける柱の煎断破壊の状 況 (詰験体 8CWF-BO の負側加 力型験結果)

間の補強ブロック壁の水平断面積

${ }_{B} F_{s s}$ : 補強ブロックの全断面積汇関する見掛忖の スリップ状剪断強度

各試験体について (3.39) 式及び (3.40) 式より補強 ブロック壁の全断面積に関する見掛けのスリップ状剪断 強度 ${ }_{B} F_{s s}$ を求めてみると全断面積に関する見掛けの圧 縮強度 ${ }_{B} F_{C}$ の約 $1 / 6$ となつて㧍り、斜張重裂発生時の
剪断尤力度 $\tau_{c r}$ と大差がふい(第 3.9 表参照)。このこ とは重裂荷重から最大耐力までの荷重増加分のほとえど を周辺架構隹依存していることを意味して招り、単独架 構 $\mathrm{F}$ 及び架構付補強 ブロック壁の $Q-R$ 曲線を付合せ ることによつても実証される。ゆ兑に周辺架構の補強ブ

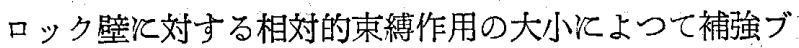
ロック壁が剪断破猿を起すか、周辺架構の部材端が曲げ 破壊を起すかの違いはあつてる、補強ブロック壁の最大

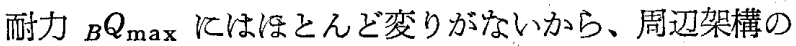
強弱関係应く

$$
{ }_{B} Q_{\max } \doteqdot A^{\prime}{ }_{w}{ }^{B} F_{C}
$$

\begin{tabular}{|c|c|c|c|c|c|c|}
\hline $\begin{array}{l}\text { 詿験体 } \\
\text { 符 }\end{array}$ & $\begin{array}{l}Q_{\max } \\
(\text { ton) }\end{array}$ & $\begin{array}{l}{ }_{B} Q_{\max } \\
\text { (ton) }\end{array}$ & $\begin{array}{c}B_{F} F_{s s} \\
\left(\mathrm{~kg} / \mathrm{cm}^{2}\right.\end{array}$ & $\frac{{ }_{B} F_{s s}}{{ }_{B} F_{c}}$ & $\mid \begin{array}{c}\tau_{c r} \\
\left(\mathrm{~kg} / \mathrm{cm}^{2}\right)\end{array}$ & $\frac{B F_{s s}}{\tau_{c r}}$ \\
\hline BWF-1 & 30.3 & 22.9 & 10.0 & 0.185 & 11.2 & 0.90 \\
\hline BWF-2 & 27.9 & 20.3 & 8.9 & 0.165 & 8.6 & 1.03 \\
\hline 平均值 & 29.1 & 21.6 & 9.5 & 0.175 & 9.9 & 0.96 \\
\hline & $\begin{array}{l}A^{\prime}{ }_{w}: \\
{ }_{B} F_{C}=5\end{array}$ & $\begin{array}{c}={ }_{B} Q_{\max } \\
A_{w}^{A^{\prime}} \\
\text { 補強ブロ } \\
{ }_{B} Q_{\max }= \\
Q_{\max } \\
{ }_{F} Q_{\max }\end{array}$ & 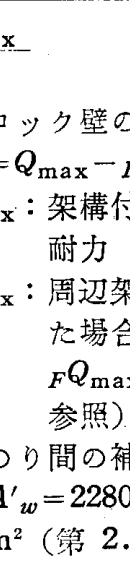 & 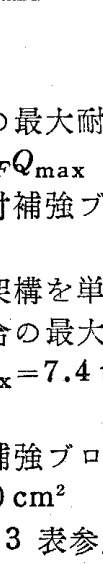 & $\begin{array}{l}\text { 拐力 } \\
\text { ジロック壁 } \\
\text { 独架構と } \\
\text { 耐力 } \\
\text { ton (第 } \\
\text { ック壁の } \\
\text { 照) }\end{array}$ & $\begin{array}{l}\text { の最大 } \\
\text { 見做乙 } \\
3.7 \text { 表 } \\
\text { 水平断 }\end{array}$ \\
\hline
\end{tabular}

を与克、(3.39) 式の累加強度式によつて架構付 補強ブ ロック壁の最大耐力 $Q_{\max }$ 算定して差支觉ない。

第 3.9 表 架構付補強ブロツク壁飞於汁る補強ブロッ ク壁の全断面積化関する見掛けのスリツプ状剪断強度

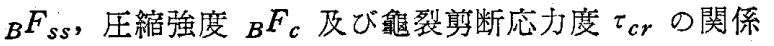

架構付補強ブロック壁法補強ブロック壁の剛性が低く 且つ周辺架構と補強ブロック壁の接触面が劋れるため、 補強ブロック壁だけが破壊し、周辺架構註補修可能と云 う状態を期待することはむずかしい。

又補強ブロック壁の補強朌量を多く望んでも、後積み とした場合には周辺架構へのアンカーが充分できにくい から、構造耐力の面からこれ沉規定を設けてその効果を 期待することは無理であらう。

\section{$\$ 3.4$ 終局耐力について}

i. 単独架構 $F$

最大耐力 $Q_{\max }$ 飞達した後も耐力を保持したま」かな り大きい剪断変形 $R$ 亿耐える（第 3.6 図及ご附 5.1 図 参照)。
ii. 架構付鉄筋コンクリート壁 CWF 
最大耐力 $Q_{\text {max }}$ に達した後急激江耐力を減じ（第 3.2 図参照)、剪断変形 $R$ の増大にともなつて壁部のコンク リートが剝落を始め、無筋壁にあつては特飞著しい(附 5.2 図 5.9 附図参照)。ゆ光飞炎害時の危険防止対策 の面からも有筋壁とすることが望をしい。

終局耐力 $Q_{\mathrm{ult}}$ 悔雑な破壊機構化支配され、解析的 方法によつてその数値を与えることは不可能と思われる が、最悪の場合には壁面が全然きかなくなり、周辺架構 が単独架構として働らくものと見做した場合の終局耐力 $Q_{\mathrm{u} 1 \mathrm{t}}$ まで低下するものと見なけれ济六るまい（第 3.1 表参照)。

iii. 架構付補強ブロック壁 BWF

架構付鉄筋コンクリート壁の項沉於て述べたとととほ よ゙同じことが云える（第 3.6 図、附 5.10 図、附 5.11 図 及び第 3.1 表参照)。

\section{$\S 3.5$ 補強問題について}

壁筇及び周辺架構部材の主筋に貼付して電気抵抗線歪 計の結果を検討すると、鲌裂が歪計の位置に生じた場合 と重裂が歪計の位置をはずれた場合の值には大きな開き がある。ゆえにその結果から直ちに定量的な結果を引出 すととはむずかしく、今後更に検討の要がある。本項で

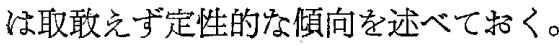

斜張重裂を横切る部分の壁筋についてその引張応力 度 $s_{t} \sigma_{t}$ 調べてるると、中央部の縦筋が一番大きい。次 そは中央部の横筋が大きく、周辺架構飞近い横筋は前者 そ較べて小となる。壁中央部の綎箊の引張応力度 $s_{t}{ }_{t}$ と 剪断変形 $R$ の関係は第 3.16 図のように盾とえで直線

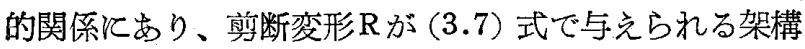
の許容剪断変形 $R_{a} \doteqdot 2.3 \times 10^{-3}$ 亿達するまでに壁筋の一 部は局部的に降伏を起していることが認められる。この ことは終局時に於て壁中央部の鉄筋が破断することによ つて子裏付けられる (第3.15 眓参照)。併乙壁筋全部の 平均引張応力度はかなりこれょり低い。

斜張車裂発生後の壁は圧力場を形成し、剪断力が加

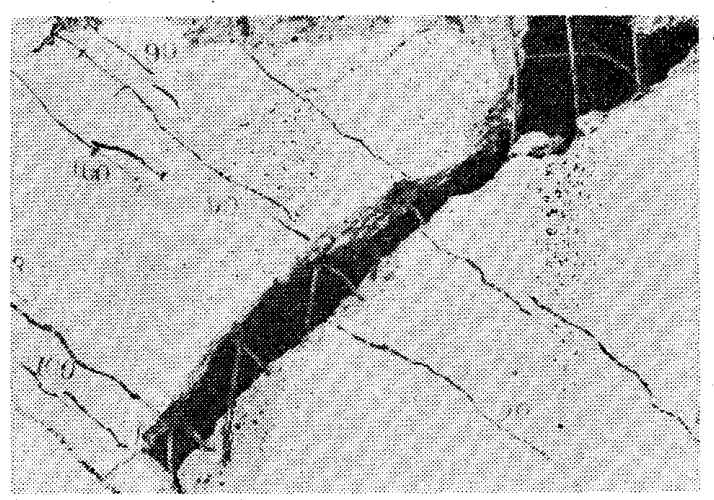

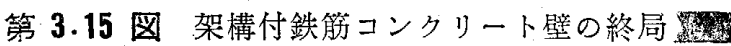
状態飞於ける壁中央部の縦筋の破断状況（試験 体 $8 \mathrm{CWF}-\mathrm{BB}$ の負側加力詿験結果)

わると膨張すると とになり、周辺架 構はこれを束縛す る「たが」の役を なすととはすでに 別報) 飞於て理論 的に述べて执いた が、全体の変形 (附 3.2 図 附 3.9 困参照) 及び 第 3.17 図江示し た梁中央部外側主 筋の引張応力度 $s^{\sigma_{t}}$ 飞剪断変形 $R$ の関係加 、周辺 架構が外側へ江占 み出して抵抗して いるととが実験的 にも襄付けられて 认る。第 3.17 図 は梁中央部の外側 主筋泟関する引張 応力度 $s_{t} \sigma_{t}$ 剪断 変形 $R$ が活じ直線 的関係泟あること を示すととるに、 周辺架構のはらみ 出しに対して壁筋 がかなり有效倠 いてくれることも 示している。併し 架構付壁の最大耐 力 $Q_{\max }$ が周辺架 構往よて支配さ

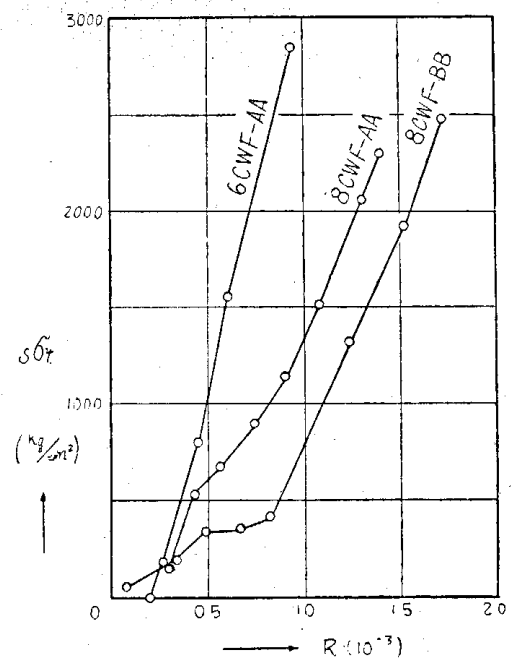

筹3.16図 架構付鉄筋コンクリート 壁の斜張箍裂発生後江於ける壁中央 部の縦筋飞関する引張応力度 $s^{\sigma_{t}}$ と 剪断変形 $R$ の関係

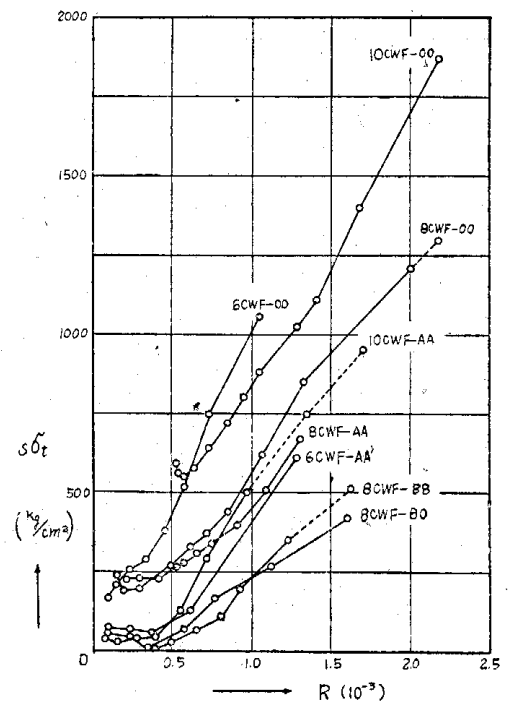

第 3.17 図，架構付鉄筋コンタリー 卜壁の斜張眶裂発生後に於ける周辺 架構梁中央部の外側主筋飞関する引 張応力度 $s^{\sigma_{t}}$ と剪断変形 $R$ の関係

れる場合でるその直接原因となるのほ部材中央の曲げ破 壊よりはむしろ部材端の剪断破壊と考学られること（§ 3.3 参照)、又隣接架構にも壁が皇つている 場合には 周辺架構のはらみ出し現象は相殺されることなどを考光 ると、部材中央の曲げと対する補強と云う問題よりは部 材端の剪断補強の方がより大切であるように思われる。

壁化無数の斜張亀裂が発生し、コンクリートが斜張力 を全く負担できないような完全圧力場状態を考克、壁筋 の抵抗を無視して本試験体のような 1 スパンの耐震壁の 梁端の剪断力 $F B$ を求めると次のよ 5 になる。

$$
{ }_{F B} Q=\frac{1}{2} Q
$$

壁のスリップ状剪断破壊と梁の剪断破壊が同時に生じ た無筋壁の試験体 8 CWF-00（第 3.1 表参照）について 
最大耐力 $Q_{\max }=90.1$ ton（第 3.1 表参照）に於ける梁 端の剪断力 $F B Q_{\max }$ 及び剪断応力度 $F B^{\tau}$ max と

$$
\begin{aligned}
& { }_{F B} Q_{\max }=\frac{1}{2} Q_{\max }=\frac{90.1}{2}=45 \text { ton } \\
& { }_{F B} \tau_{\max }=\frac{F B Q_{\max }}{b j}=\frac{45,000}{20 \times 27 \times 0.9}=92.5 \mathrm{~kg} / \mathrm{cm}^{2}
\end{aligned}
$$

となり、試験体の梁端断面 (第 2.1 図参照)の剪断耐力と しては 2 倍以上も大きい值であることが推論される ${ }^{14)} 。$ このことは、壁のコンクリントが一部の斜張力を負担 し、不完全圧力場状態を呈しているためであつて、周辺 架構の束縛反力としては、完全圧力場を仮定して求めた 值の $\frac{1}{2}$ 位を考えて㧧けば允分であることがうから゙われ る。

\section{謝 …辞}

本研究は昭和 29 年度建設省住宅構造実験費及び建設 技術補助金の各一部によつて行つたものであり、資材に 関しては鋼材クラブ、セメント協会、日本コンクリート 協会の援助を受け、施工に関しては不然建築技術協会の 協力を得た。又実験の測定、実験結果の整理にあたつて 经建設省建築研究所及び東京大学生産技術研究所の各職 員及び東京都立大学工学部建設工学科の学生諸君の御援 助を得た。関係各位に対し謝意を表します。

\section{参 考 文 献}

1) 武藤清：「構造設計法」建 築学大系 14 、彰国社 昭 29.9

2）田辺平学：「鉄筋コンクリート版の応剪抵抗に関 する研究」神戸高等工業学校紀要、第 2 巻、昭5.6

3）田辺平学、勝田千利、東東造：「耐震壁に関する 研究第 1 報 第 4 報」建論、昭 8 、昭 9 、建雑、昭 10.3 、建諭、昭 10

4) 坪井善勝、富井政英：「鉄筋コンクリート無開口 及び有開口単独壁の剪断抵抗関する研究」建 論 49 号、昭 29.9
5) 坪井善勝、富井政英：「鉄筋コンクリート無開ロ 単独壁の剪断抵抗に関する研究」建論 47 号、昭 28.9

6) 坪井善勝、富井政英：「直交異方性弹性版理論飞 よる鉄筋コンクリート壁の龜裂発生後に於ける剪 断抵抗の解析」建論 48 号、昭29.3

7) 坪井善勝、富井政英：「鉄筋コンクリート架構の 剪断抵抗と接合部の補強効果に関する研究」建諭 50 号、昭 30.3

8）坂静雄：「鉄筋コンクリートの研究」産業図書株 式会社、昭 29.12

9）浜田稔、白山和久：「鉄筋軽量コンクリート造設 計規準解説」日本建築学会特殊コンクリート構造 設計規準、同解説、昭 27.11

10) 坪开善勝 : 「耐震壁の応力解析（壁付 ラーメンの 剪断変形)」建論 46 号、昭 28.3

11）大崎順彦：「鉄筋コンクリート終局強度実用設計 式」建論 46 号、昭 28.3

12）梅村魁：「鉄筋コンクリート断面の終局強度決定 法について」建報 17 号、昭 27.3

13）武藤清、黒正清治：「鉄筋コンクリート二層耐震 壁飞ついての実験的研究」建論 47 号、昭 28.9

14）黒正清治：「はり、柱の終局強度—4 章せえ断 終局強度」鉄筋コンクリート構造の諸問題、昭和 30 年版、日本建築学会

\section{附図の説明}

附 1.1 図 附 1.11 図: 各誈験体の配筋図

附 2.1 図 附 2.11 図: 各試験体の正側加力詿験 に於ける龜裂発生前の変形（但し附 2.1 図は龜裂 発生後の変形をも含む)

附 3.1 図 附 3.11 図: 各訊験体の正侧加力試験 に於ける龜裂発生後の変形

附 4.1 図 附 4.11 図: 各坛験体の正側加力試験 に於ける龜裂の状況

註：龜裂の脇に捺印してある数值は該曐裂部発 生時の対角線方向荷重 $P$ (ton) を示す。

附 5.1 図 附 5.11 図: 各詰験体の負側加力試験 に於汀る終局の状況 

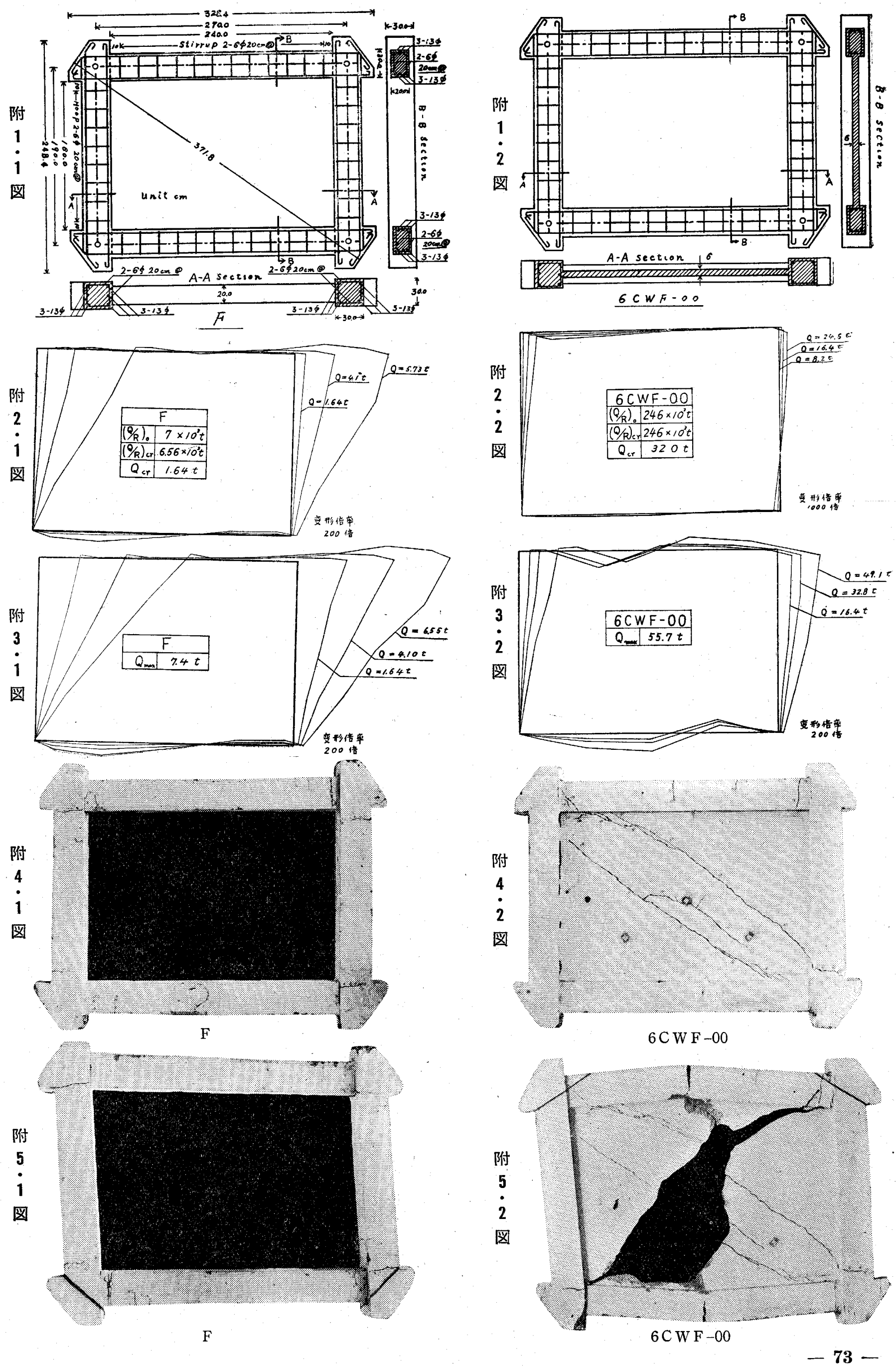

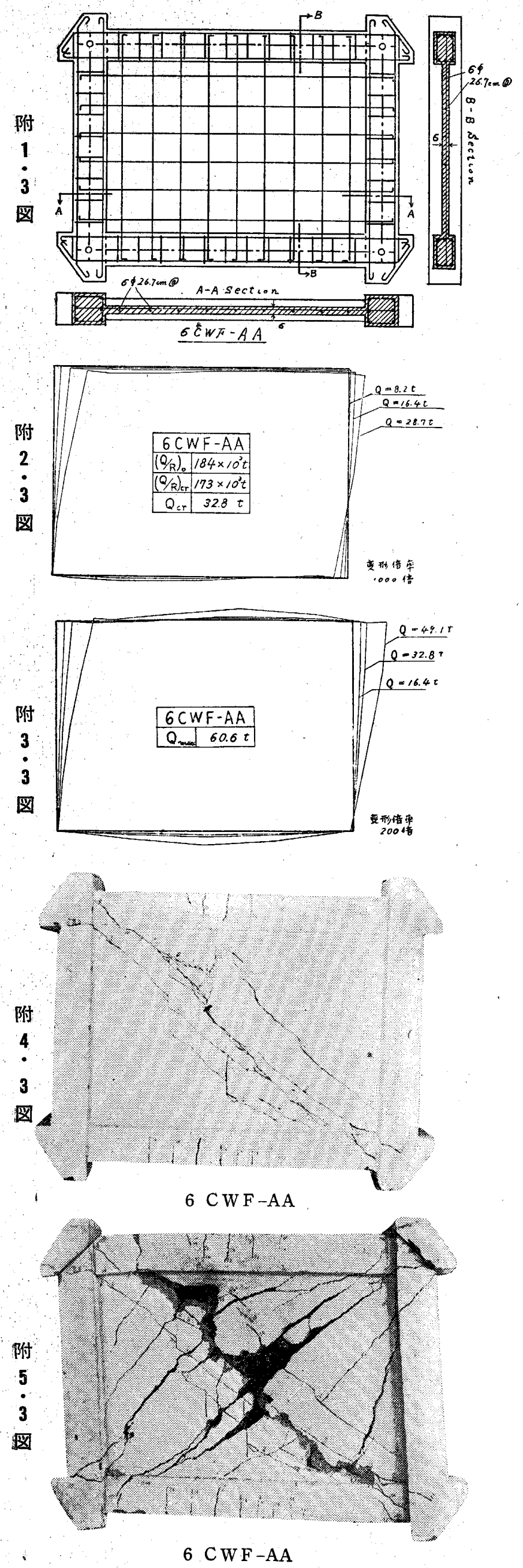
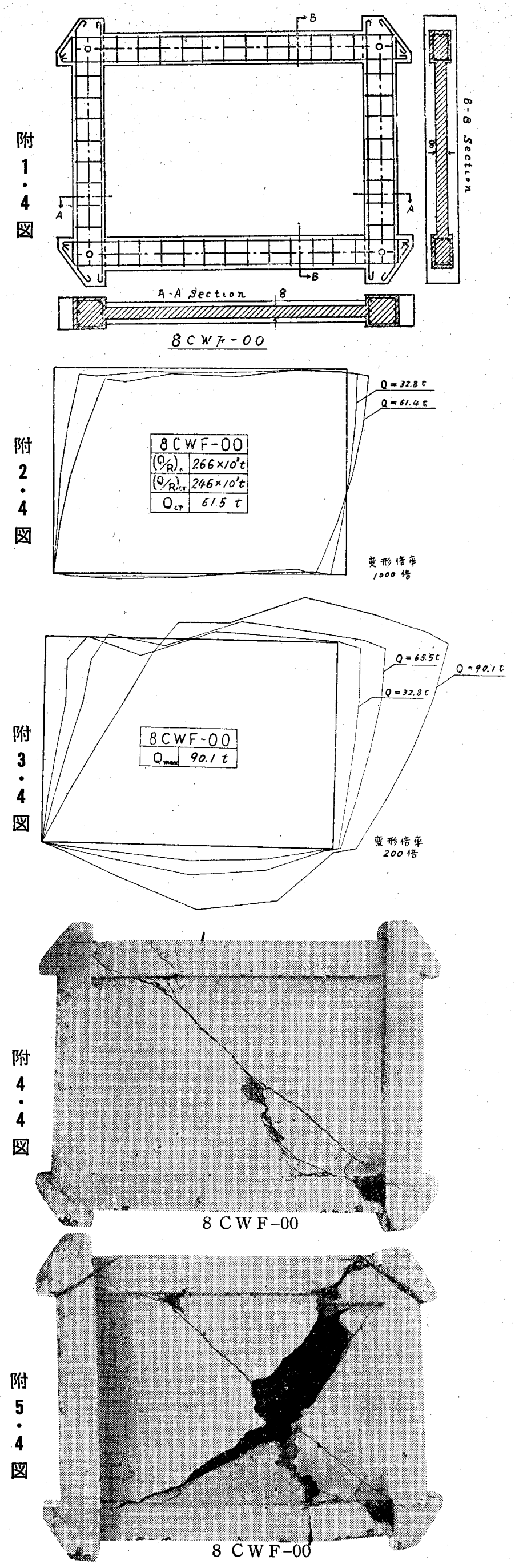

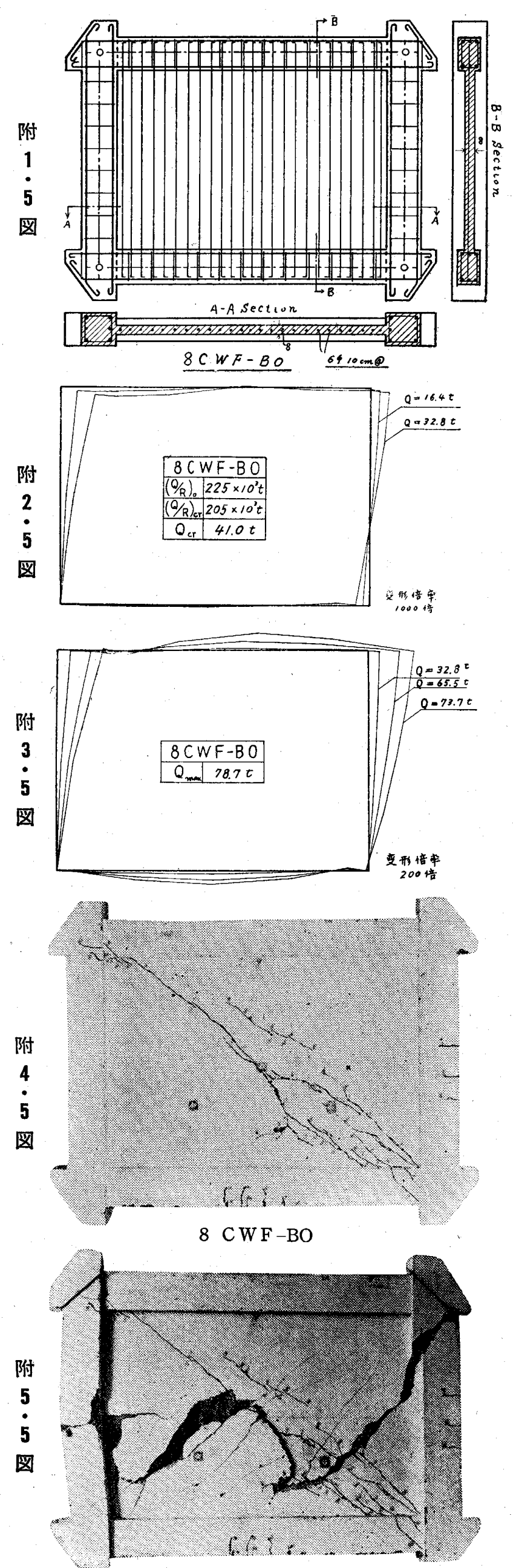

$8 \mathrm{CWF}-\mathrm{BO}$
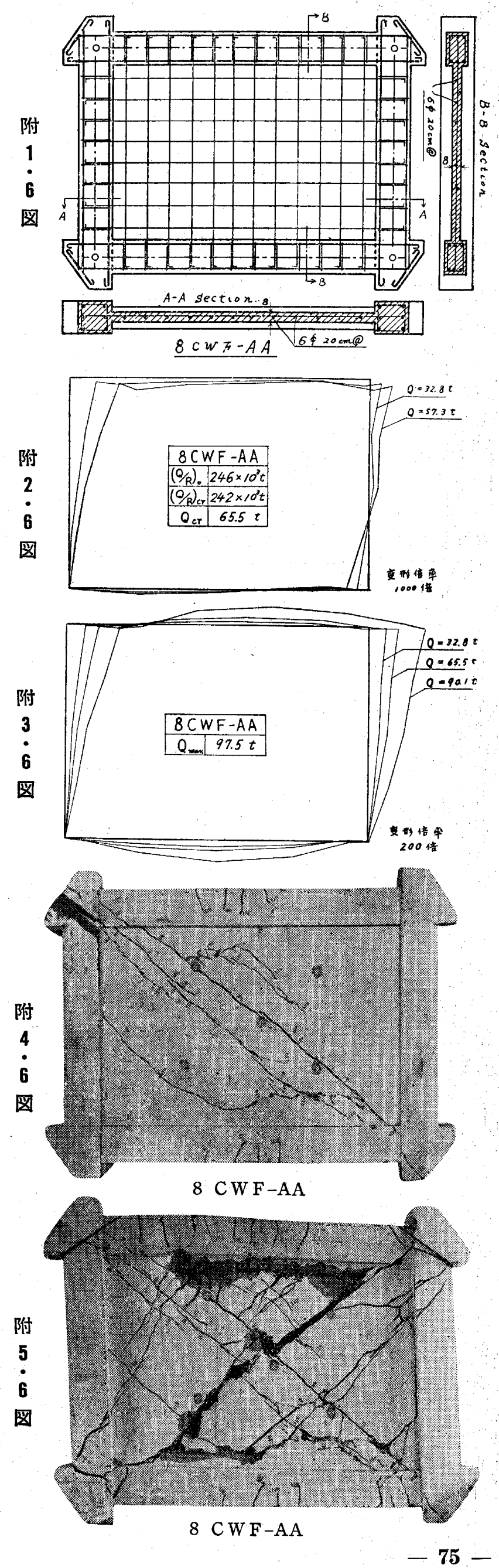

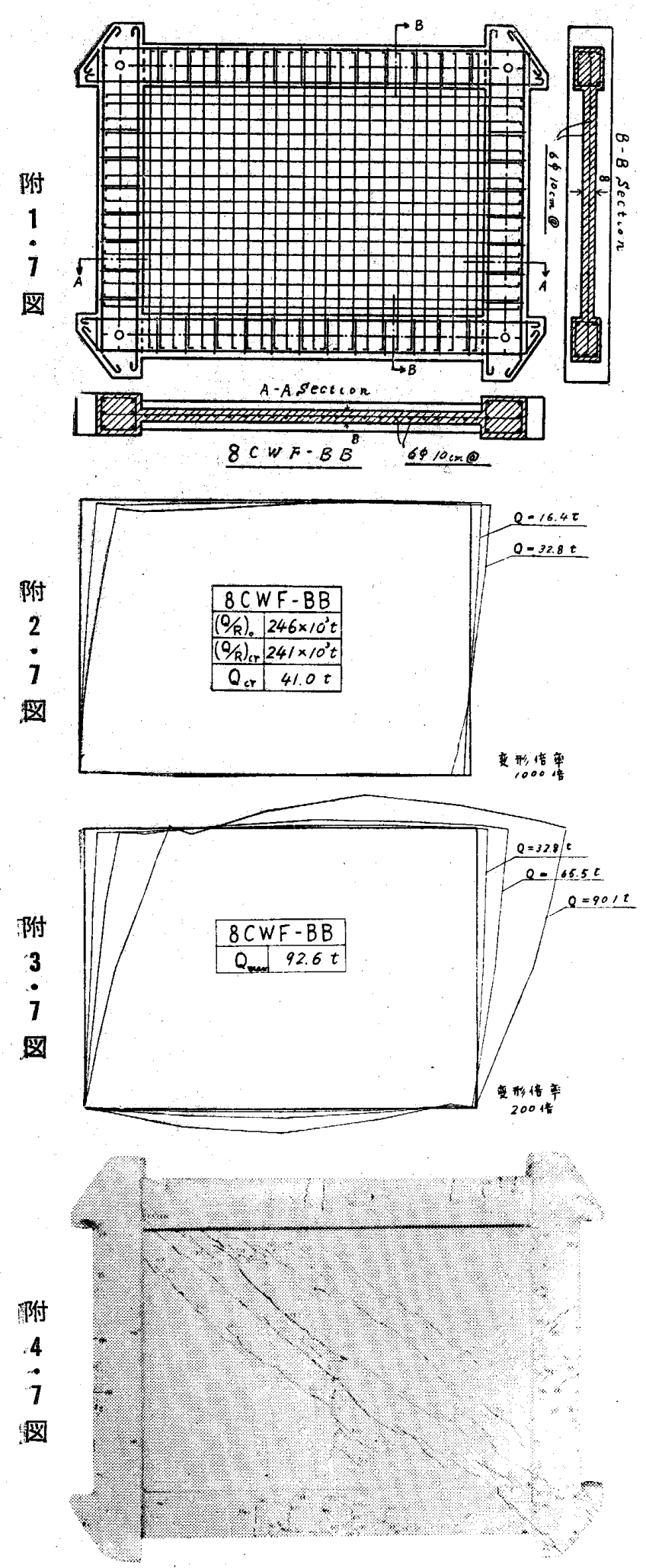

$8 \mathrm{CW}$ - $-\mathrm{BB}$

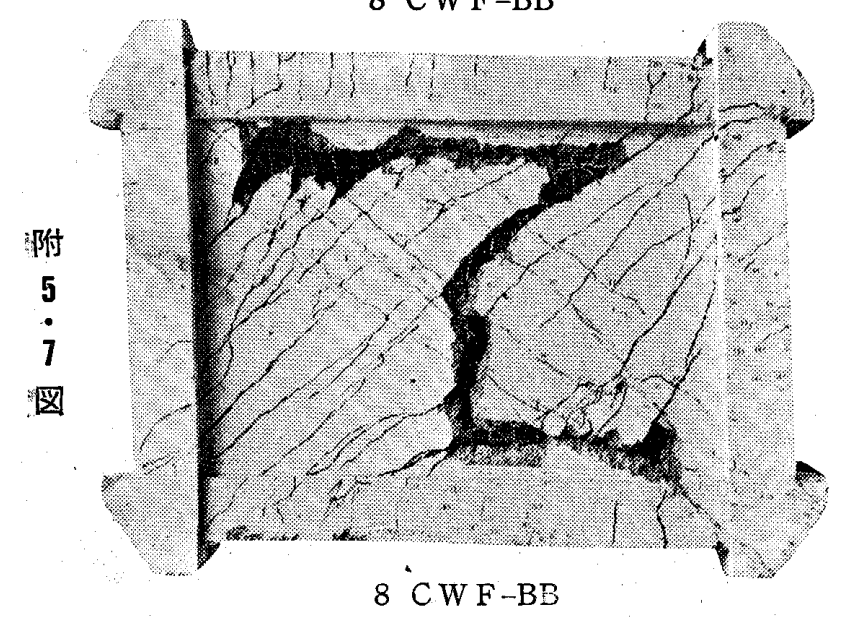

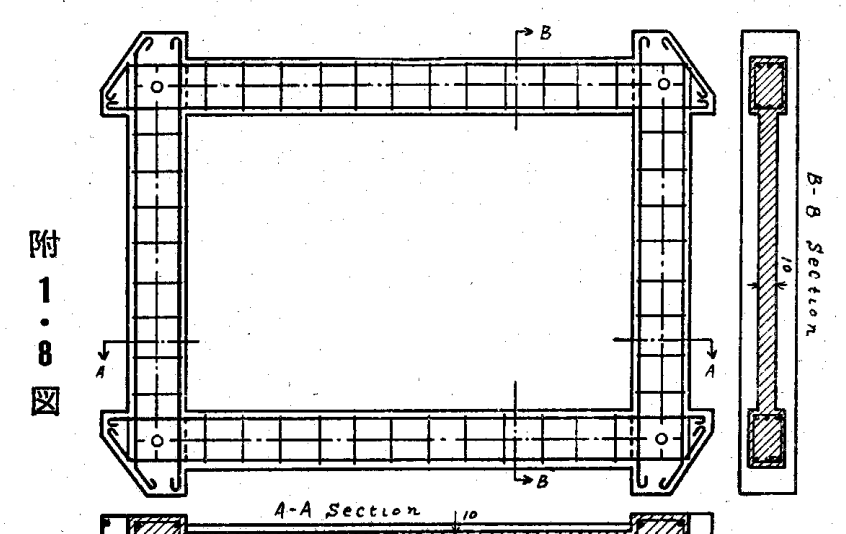
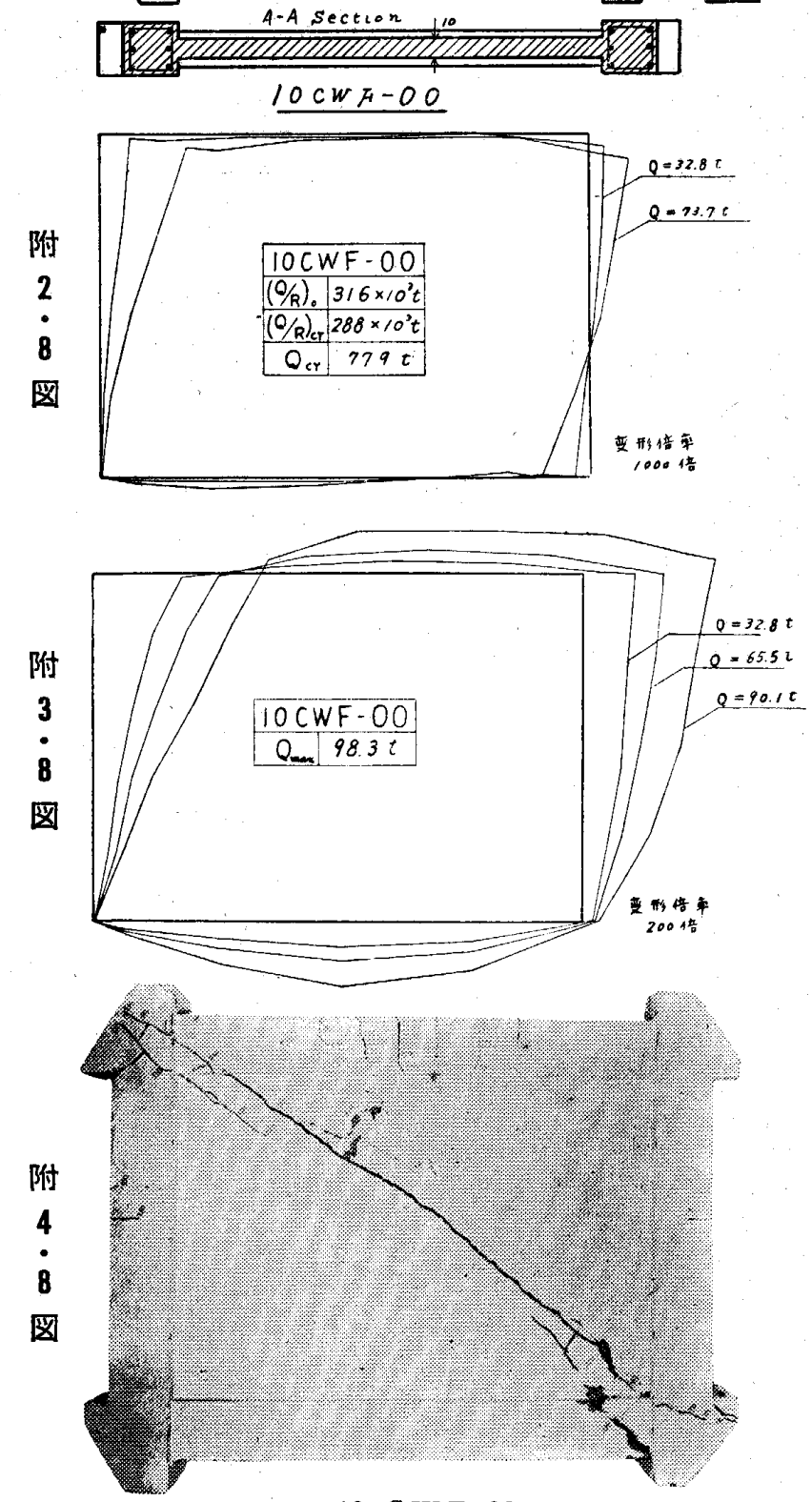

$10 \mathrm{CW} \mathrm{F}-00$

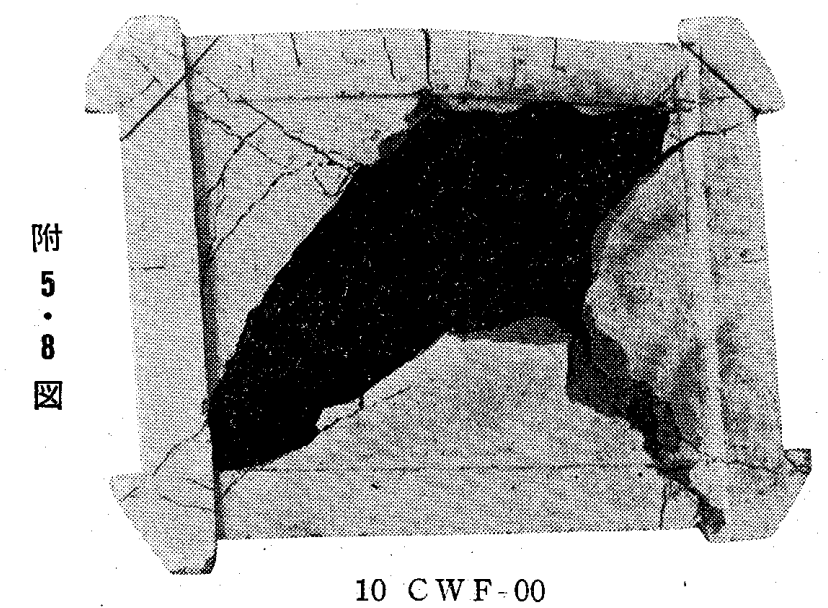



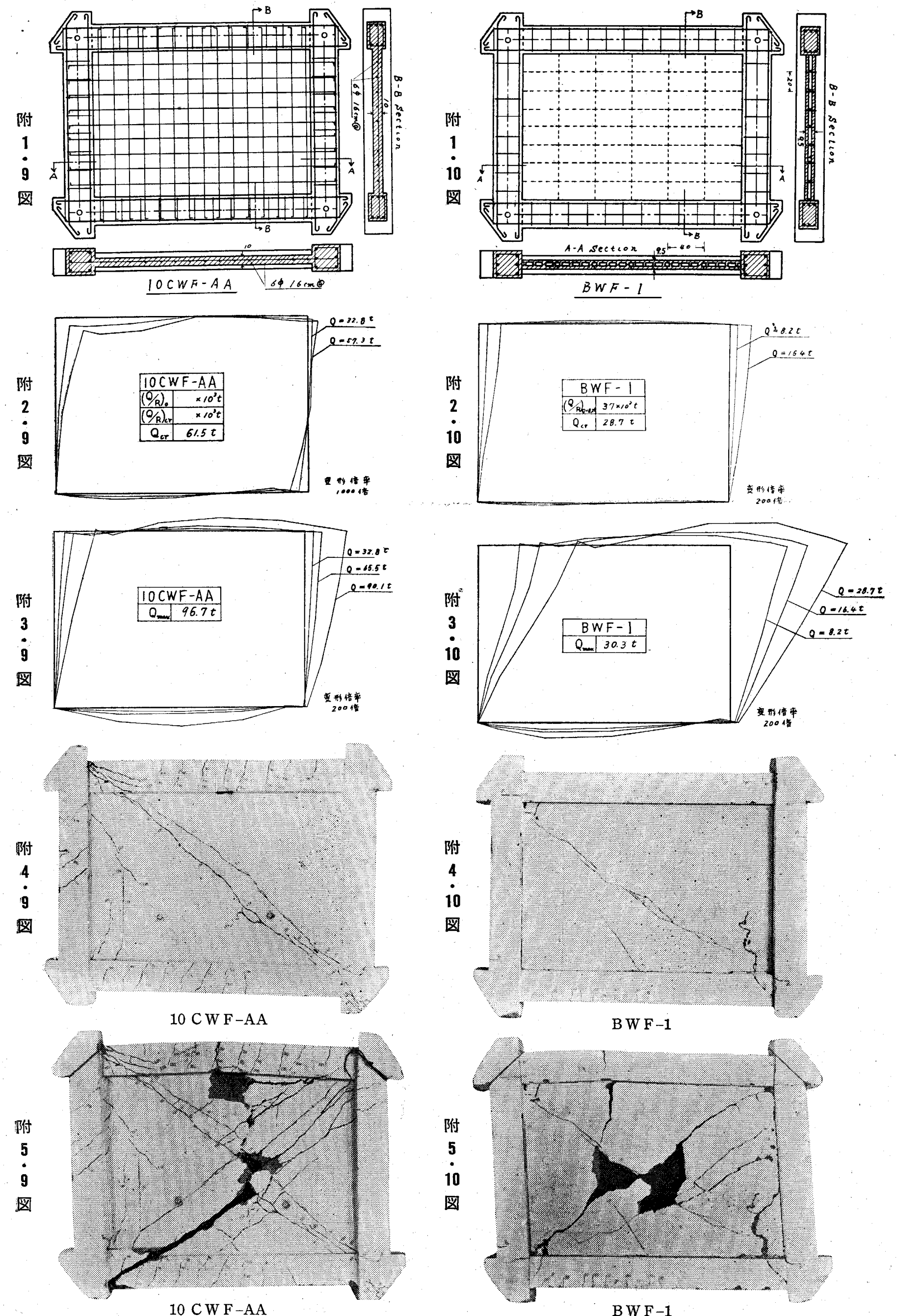

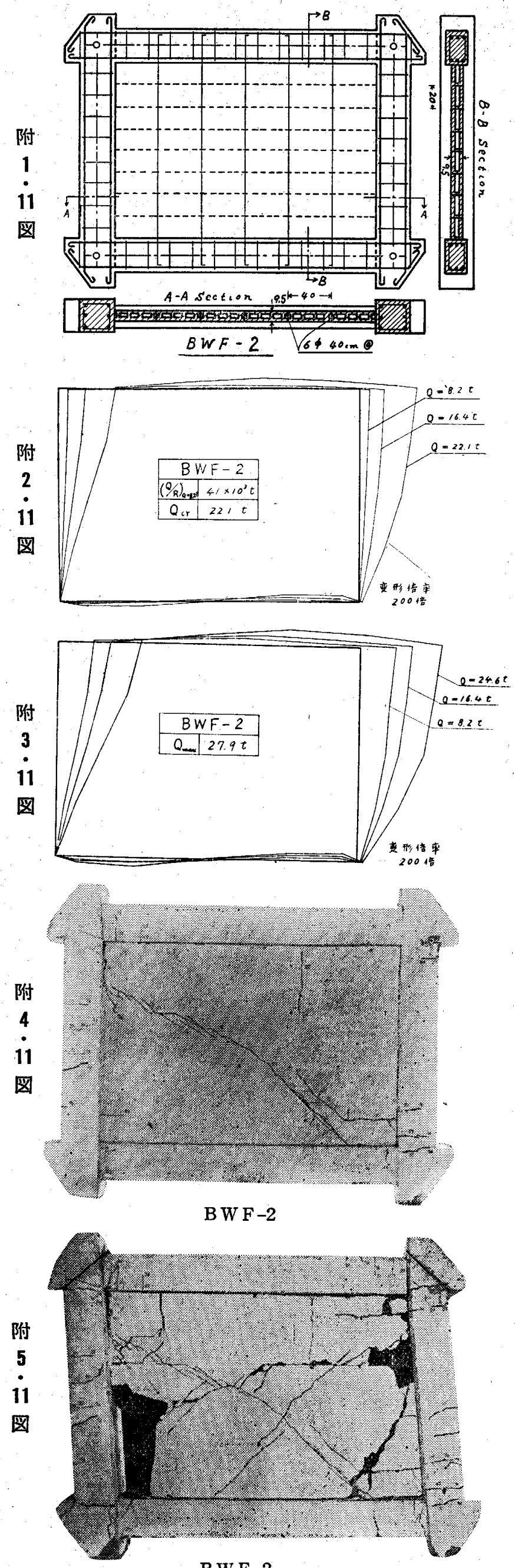